\title{
MONITORING SYSTEM OF THE ROAD EMBANKMENT
}

\author{
Mikołaj Miśkiewicz $^{1 \bowtie}$, Błażej Meronk ${ }^{2}$, Tadeusz Brzozowski ${ }^{3}$, Krzysztof Wilde $^{4}$ \\ 1, 2, 4 Dept of Mechanics of Materials and Structures, Faculty of Civil and Environmental Engineering, \\ Gdansk University of Technology, ul. Narutowicza 11/12, Gdańsk, 80-233, Poland \\ ${ }^{3}$ Keller Polska Sp. z o.o., ul. Rdestowa, 51A, Gdynia, 81-577, Poland \\ E-mails: ${ }^{1}$ mikolaj.miskiewicz@wilis.pg.gda.pl; ${ }^{2}$ blazej.meronk@wilis.pg.gda.pl; ${ }^{3}$ tbrzozowski@keller.com.pl; \\ ${ }^{4}$ krzysztof.wilde@wilis.pg.gda.pl
}

\begin{abstract}
The paper presents the analysis of the monitoring system of the embankment supported on concrete columns and overlaid by a load transfer platform with the embedded steel grid. This field investigation was to study the complex interaction between the columns, the load transfer platform layer, and steel grid via in situ measurements during erection and live loading of the embankment. The study was focused on the behaviour of steel grid and the behaviour of the outer rows of columns since there are limited reference data available for this problem. The system was designed to inform the engineers about the condition of the embankment at every stage of construction and during standard operation of the road. The measurements brought the information on strain variations of steel grid, concrete columns, and structural settlement and provided necessary evidence for the embankment numerical model validation.
\end{abstract}

Keywords: embankment, geotechnics monitoring, measurement, structural health monitoring (SHM).

\section{Introduction}

An Observational Method (OM) is recommended in the PN-EN 1997-1:2008 Eurocode 7: Geotechnical Design Part 1: General Rules as a possible method of verification of limit states complemented by the use of calculations, adoption of prescriptive measures or experimental models and load tests or a combination of the above methods. In current everyday design practice, most cases are based on engineering calculations only, without or with a limited use of the observational method (Miśkiewicz et al. 2017a). In 2002 a European geotechnical forum (GeoTechNet) published a document (Patel et al. 2007) promoting modern design tools, including the application of the Finite Element Method (FEM) and the observational method to reduce costs and programmes on engineering projects without any safety compromise.

The paper presents thoroughly the observational method, based on Structural Health Monitoring (SHM) system combined with numerical simulations of an innovative solution for road embankment. Steel grid reinforcement strengthened the embankment and founded on Controlled Stiffness Columns (CSC). The study is directed to knowledge acquisition on the intricate (complex) interaction between the CSC columns, the Load
Transfer Platform (LTP) layer and steel grid via in situ measurements during the erection of the structure and live loading (Topolnicki 2013). The study was focused on the behaviour of the steel reinforcement and the behaviour of the outer rows of columns since this component is crucial for proper operation of the embankment. Similarly, to the systems described in Kaminski et al. (2015), Mariak et al. (2016a, 2016b), Miśkiewicz et al. (2016, 2017a, 2017b), Rucka, Wilde (2013) and Wilde et al. (2013), the design team was created to provide a product meeting the prior stated conditions. The number of sensors and geometrical size of the system should have been as small as possible, yet sufficient to provide the information about the behaviour of the steel grid, reinforced concrete columns, and settlement of the structure. Appropriate design of the LTP layer with steel grid should reduce significant horizontal forces acting on the outer CSC columns, subsequently, and reduce their bending. The obtained measurement data are bound to aim the subsequent back analyses and FEM computations to develop and verify of the authors design procedures and to assess better the risk involved in similar ground strengthening projects. 


\section{Embankment and monitoring system}

The monitored embankment is located next to the bridge (Fig. 1a). It is supported on CSC columns constructed by Keller Polska Sp. z o.o. moreover, overlaid by an LTP layer with an embedded steel grid (Fig. 2). The subsoil condition near the bridge is unfavourable: over 15 meters of mud, peat and gyttja over moraine clay and fine sand. The structure of the embankment is the foundation on CSC columns diameter $360 \mathrm{~mm}$ with spacing changing from $1.4 \times 1.9 \mathrm{~m}$ to $1.6 \times 2.2 \mathrm{~m}$. At the place of the most unfavourable soil conditions, the thickness of organic soil is about $13 \mathrm{~m}$ (according to Cone Penetration Test (CPT) 20, Fig. 1b). At that location, the spacing of columns changes from $1.9 \times 1.9 \mathrm{~m}$ in the centre to $1.9 \times 1.5 \mathrm{~m}$ near the fill slopes. The columns are built of concrete C16/20. Two rows of outer columns are reinforced of UBs 160 (S355/JR steel), the LTP layer is $0.5 \mathrm{~m}$ thick, the steel grid is made of S355 steel with the rigidity of $157 \mathrm{MN}$ in the across road direction and $121 \mathrm{MN}$ in the long road direction. The design was based on ASIRI National Project (Simon 2013).

It was assumed that independent sensors working with different technologies measured the critical parameters of the embankment monitored during the progress of the construction. For example, the elongation of the steel grid was measured by a long base extensometers and small base extensometers based on vibrating wire sensors technology.

The monitoring program includes the following measurement components (Fig. 1b, Figs 2-3):

- forces in outer CSC column - 12 strain gages welded to steel beam IPE160 (4 sensors at three levels);

- distribution of vertical stresses on the columns and subsoil - load cell sensors mounted on the columns heads ( 2 sensors) and the subsoil (4 sensors);

- forces in the steel grid and horizontal displacements of steel grid - 14 strain gauges and four long base extensometers mounted to the steel grid;

- settlement of the embankment - measurements in one cross-section of the embankment, in two PVC pipes using "hydrostatic leveller";

- horizontal displacements of the outer columns measurements carried out using an inclinometer. Two steel square inclinometer tube, length about $12 \mathrm{~m}$, were installed alongside steel reinforcement in two outer columns;

- horizontal displacements of the subsoil among outer the columns - task carried out using an inclinometer. Two inclinometer PVC pipes, diameter $70 \mathrm{~mm}$ and about $16 \mathrm{~m}$ long, were installed among outer columns.

The monitoring system designers sought to create a system not requiring an electrical supply. They were looking for solutions based mostly on compatible sensors allowing simplifying the data acquisition process. Finally, vibrating wire sensors were used for monitoring strains in the steel grid and column reinforcement as well as the pressure acting on columns heads and subsoil.

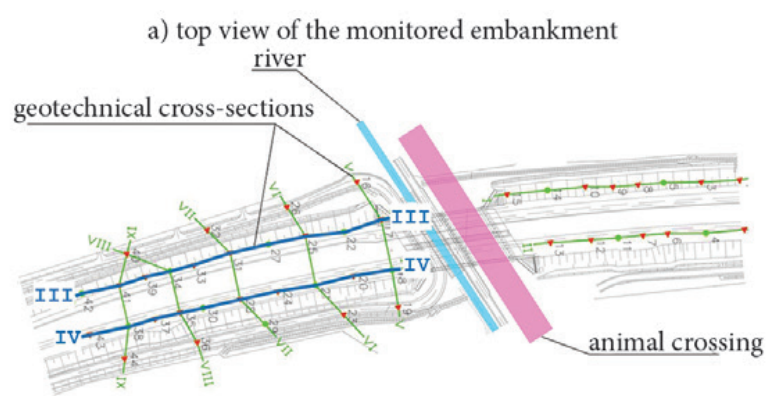

b) geotechnical cross-section IV-IV

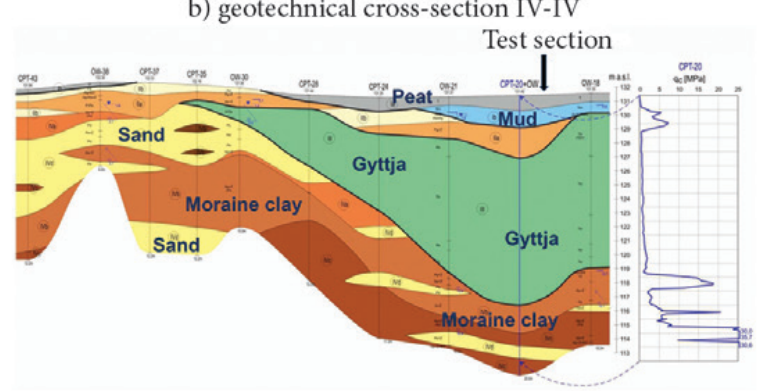

c) local of instruments in the selected cross-section of the embankment

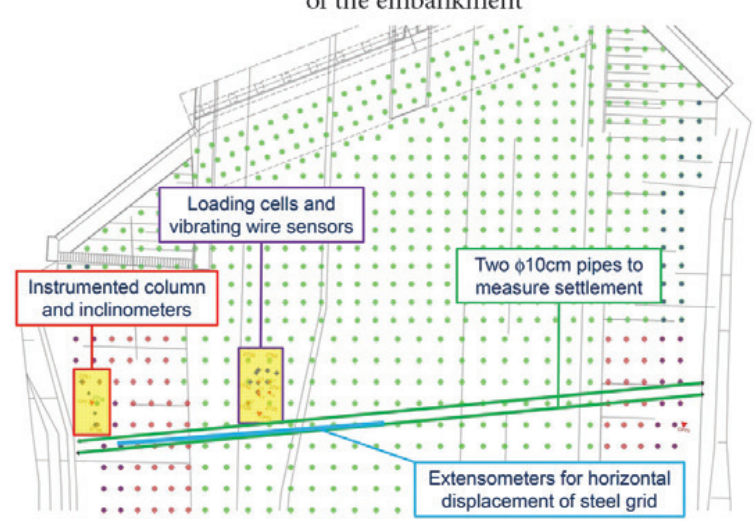

Fig. 1. Location of the monitored embankment

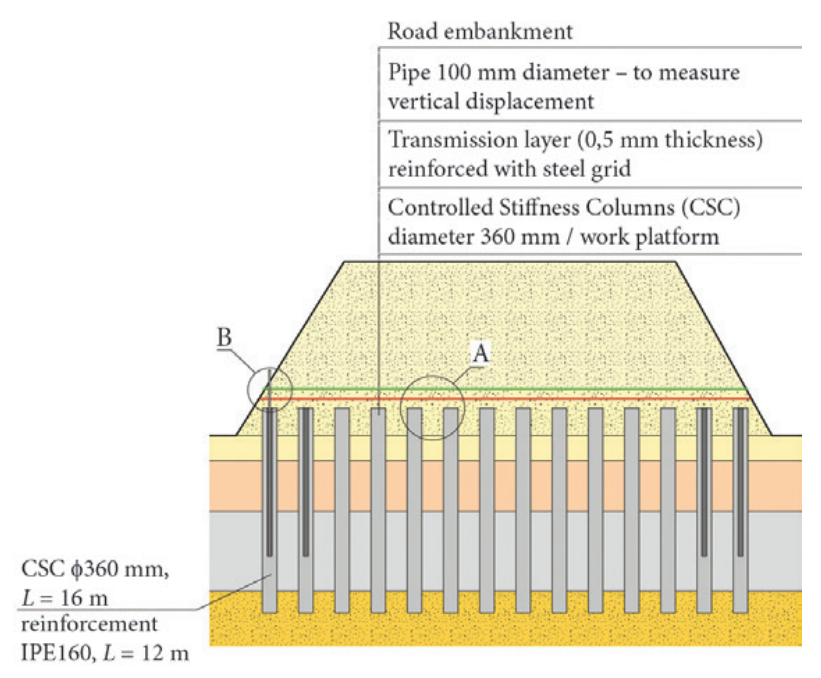

Fig. 2. Measurement scheme on cross-section of the embankment (detail A - Fig. 3a, detail B - Fig. 3b) 
a) local of measurement points of forces in steel grid and pressure on columns heads and subsoil

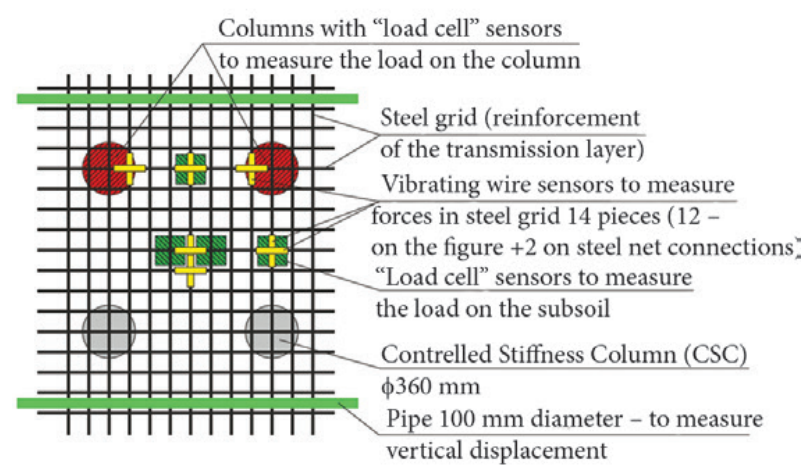

b) local of measurement points on CSC columns

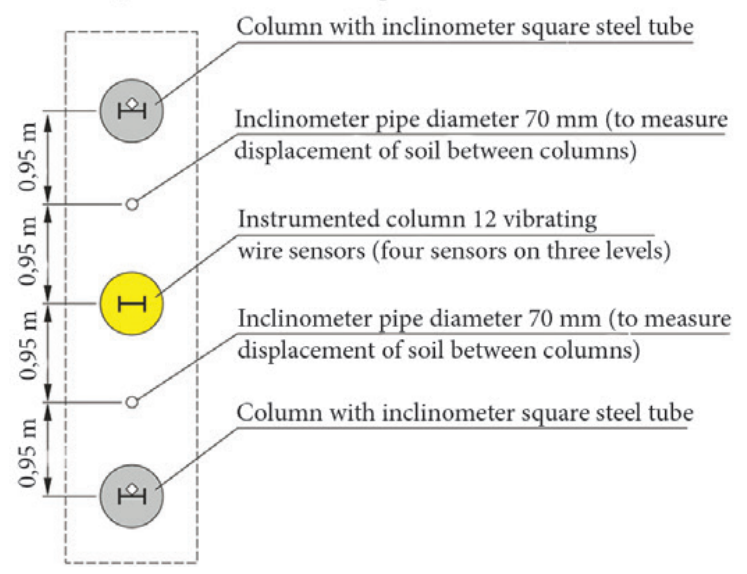

Fig. 3. Measurement details

a) strain gages installed on UBs 160 profile CSC - column reinforcement

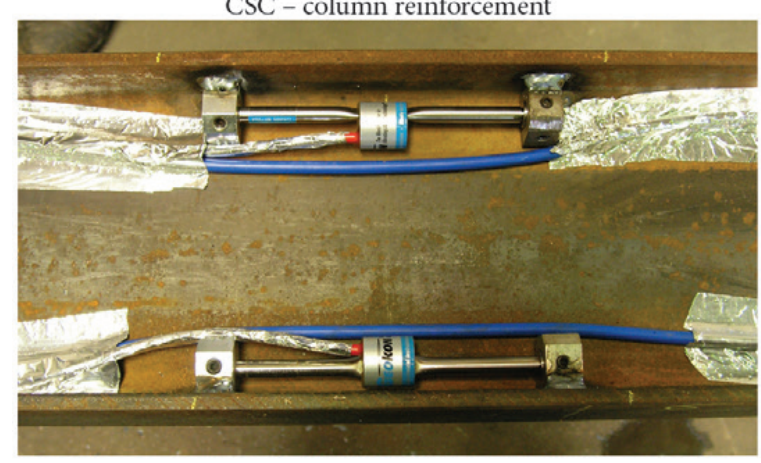

b) steel plate protecting mesureing points

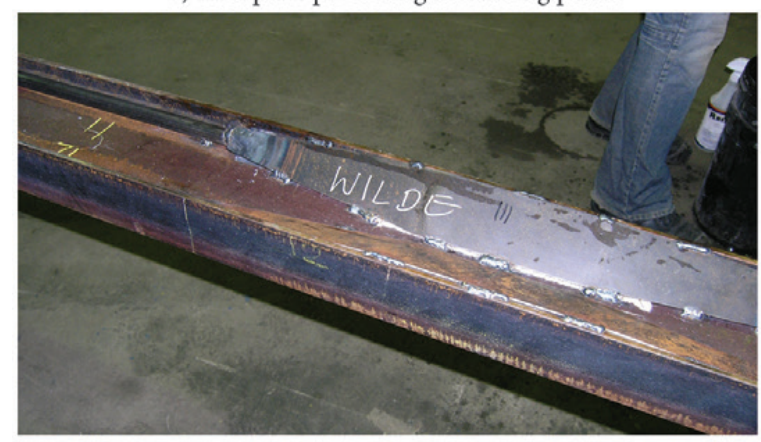

Fig. 4. Measurement points located on columns reinforcement

\section{Measurements}

The location of various components of the monitoring system is shown in Fig. 1c.

\subsection{Forces in CSC outer column}

Force identification in CSC columns was possible based on strain measurements. The vibrating wire sensors with the base $150 \mathrm{~mm}$ were applied (Fig. 4a). The sensor range is $3000 \mu \varepsilon$, resolution $1 \mu \varepsilon$, accuracy $\pm 0.5 \%$ F.S. and nonlinearity $<0.5 \%$ F.S. These sensors work in the temperature range from $-20^{\circ} \mathrm{C}$ to $+80^{\circ} \mathrm{C}$. The sensors consist of a steel wire tensioned between two mounting blocks arc welded to the steel surface. The sensors detected excellent stability over an extended period. The essential task was to protect the vibrating wire sensors and cables against possible damage during installation in the CSC column. That was why preliminary tests and calibration procedures were done in the workshop a few weeks before installation on a construction site. After the installation, steel plates (Fig. 4b) protected the sensors.

The control measurements taken after installation of the instrumented profile in the chosen column indicated that all 12 sensors were operational and that the readings were in the desired range. It confirmed that the protection and installation procedures were appropriately conducted.

\subsection{Pressure on CSC columns and subsoil}

Vertical stresses acting on the column heads and the subsoil were measured using vibrating wire earth pressure cells with diameter $230 \mathrm{~mm}$ (Fig. 5b). These cells with ranges $5 \mathrm{MPa}$ (on columns heads) and $70 \mathrm{kPa}$ (on subsoil)

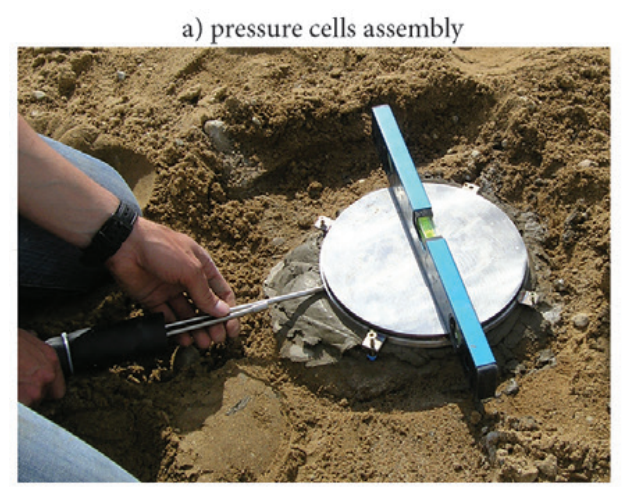

b) pressure cells before backfilling

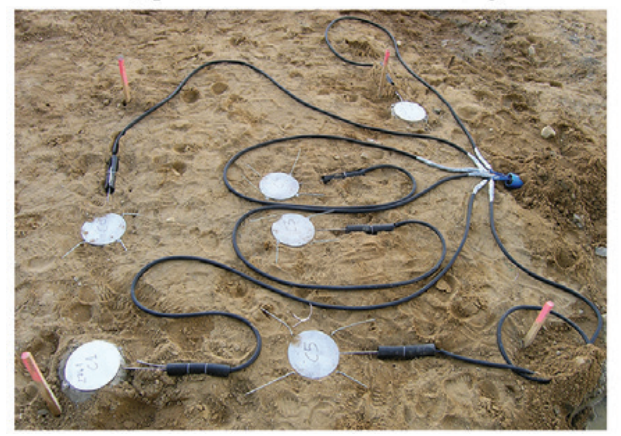

Fig. 5. Vibrating wire load cells measurement points 
showed resolution of $0.025 \%$ F.S., and accuracy $\pm 0.1 \%$ F.S. They work in the temperature range from $-20{ }^{\circ} \mathrm{C}$ to $+80^{\circ} \mathrm{C}$. The applied cells (Fig. 5a) were made of two circular stainless steel plates welded together around their periphery and spaced apart by a narrow cavity filled with de-aired oil. The change of earth pressure squeezed the two plates together causing a corresponding increase in fluid pressure inside the cell. A vibrating wire pressure transducer converted this pressure into an electrical signal, next transmitted to the readout location. The site of the applied cells is presented in Fig. 5b. The stresses acting on the ground were measured at the centre between four adjacent CSC columns and among "side" CSC columns. The cells placed on the columns were levelled and screwed (Fig. 5a). Pressure cells on the ground were placed directly on a compacted soil among the columns, fixed in positions with pins and backfilled.

\subsection{Forces in steel grid}

Two independent systems were made for a force identification in a steel grid. The first one is based on strain measurements with the use of the same type of sensors as in columns, i.e., strain gages. The second system is based on long base multiple point extensometers.

Short base vibrating wire sensors were welded to the steel grid (Fig. 6a). The works were conducted after backfilling the first part of the LTP layer (Fig. 6b). The instrumented steel grid was laid down on the compacted fill. Afterward, the vibrating wire sensors were covered with waterproof boxes to protect them from external influences. The sensor shields were constructed using plastic boxes, sealed with micro-rubber and silicone seal. While all the sensors were installed, the control measurements showed each of them operationally; the readings were within the desired range.

Unfortunately, during the fill compaction using the smallest vibrator equipment available on site, 7 of 14 strain sensors experienced excessive deformations. The vibro-compaction caused seven sensors to reach the readings above the allowable range. It was assumed that some of the sensors have been damaged and have changed their measurement parameters. Most likely, they were damaged due to excessive bending occurring during compaction and localized plastic deformations of the transmission layer and the soil underneath. Consequently, the possible readings of the remaining and still "operating" grid sensors had to be interpreted with caution and crosschecked with other measurements.

Long base extensometers measured "elongation" of steel grid sheets laid down on the ground with an overlapping. The device was made of four steel wires of different lengths (from $14.465 \mathrm{~m}$ to $23.743 \mathrm{~m}$ ) connected to steel grid sheets in selected locations, and the measuring "box" with four extensometers screwed to the steel grid at the centre of the embankment (Fig. 7). All wires were covered with PVC protection tubes. Extensometers were installed across two or three separate steel grid sheets.

\subsection{Embankment settlement}

The last element of the monitoring system, installed after backfilling previous sensors, was the embankment settlement system along the entire cross-section of the embankment. The system was based on the assembly of tubes, the location of the precise differential pressure transducer. The method is called hydrostatic levelling (Boerez et al. 2012).

Two horizontal tubes were initially installed (Fig. $8 \mathrm{a}-\mathrm{b})$. First, it was planned to install one tube beneath the transmission layer and the second one above this layer. However, because the monitoring system was a prototype, it was decided to double the measurements conducted at the top of the transmission layer. Both tubes of $10 \mathrm{~cm}$ diameter were made of PVC, corrugated outside and smooth

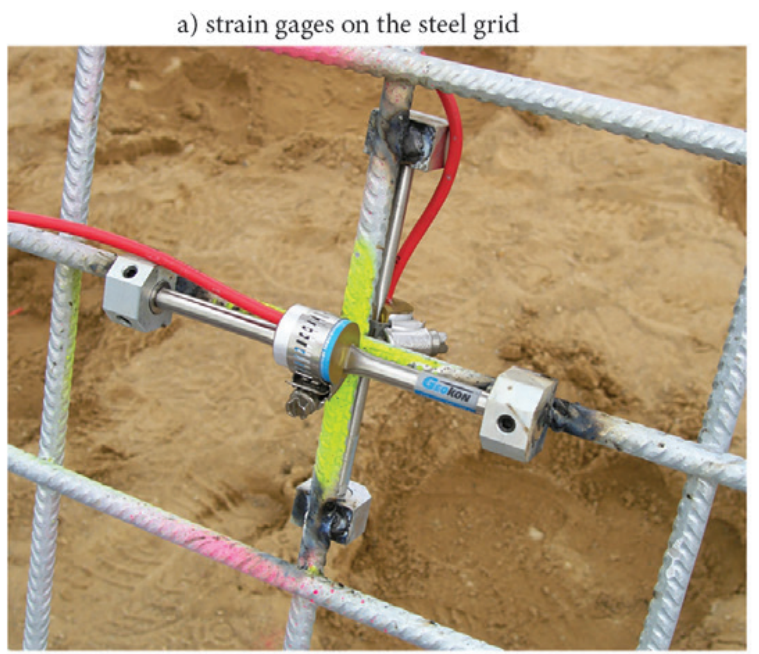

b) location of the protected sensors before backfilling

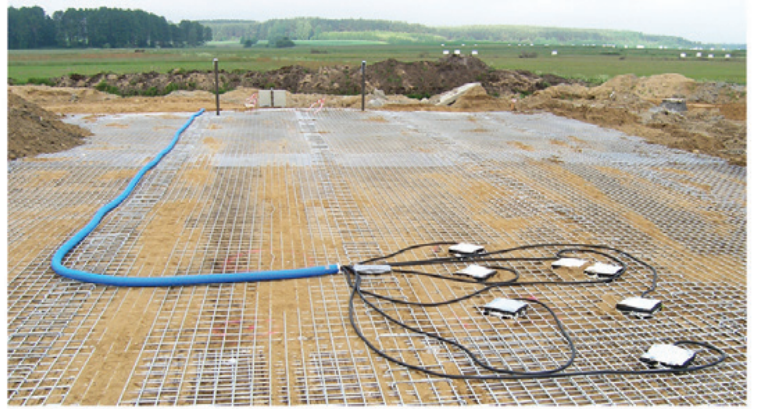

Fig. 6. Measured points on steel grid
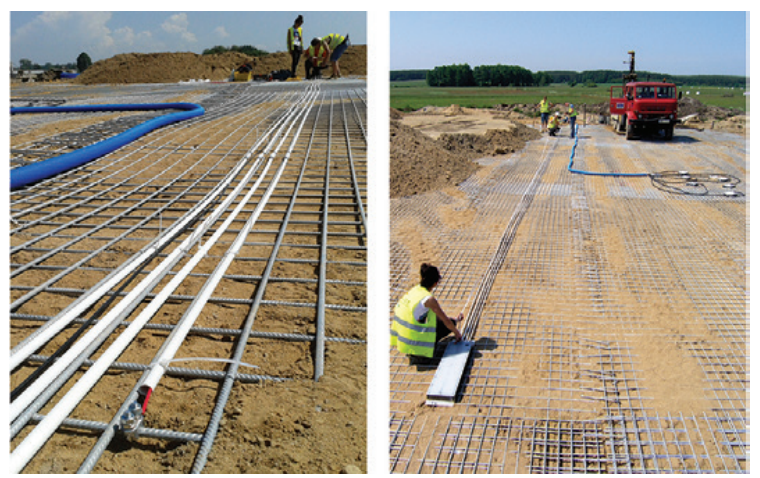

Fig. 7. Long base extensometers for measuring elongation of the steel grid 
a) installation of tubes

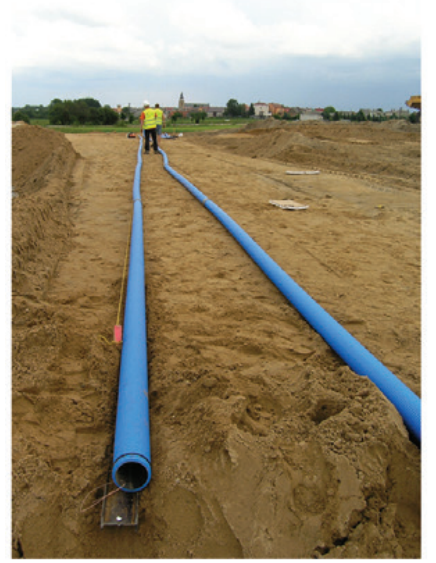

b) installation of tubes

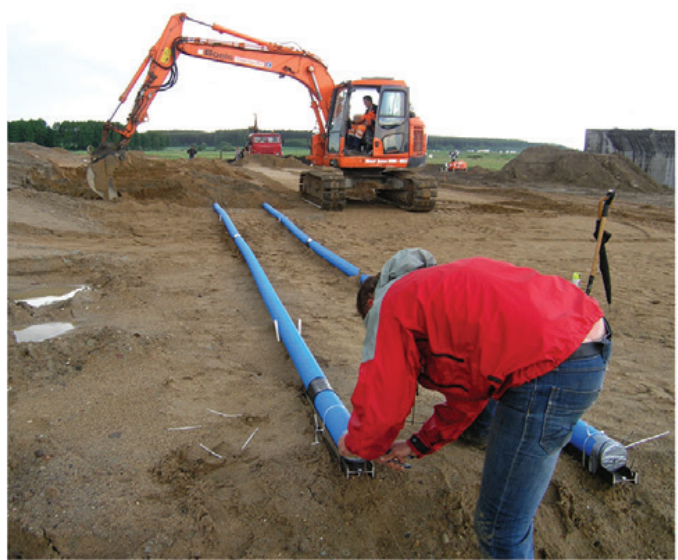

c) the first measurement after tubes backfilling

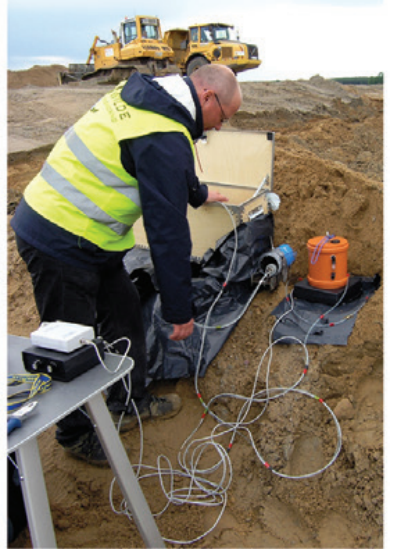

Fig. 8. Embankment settlement measurement by hydrostatic levelling

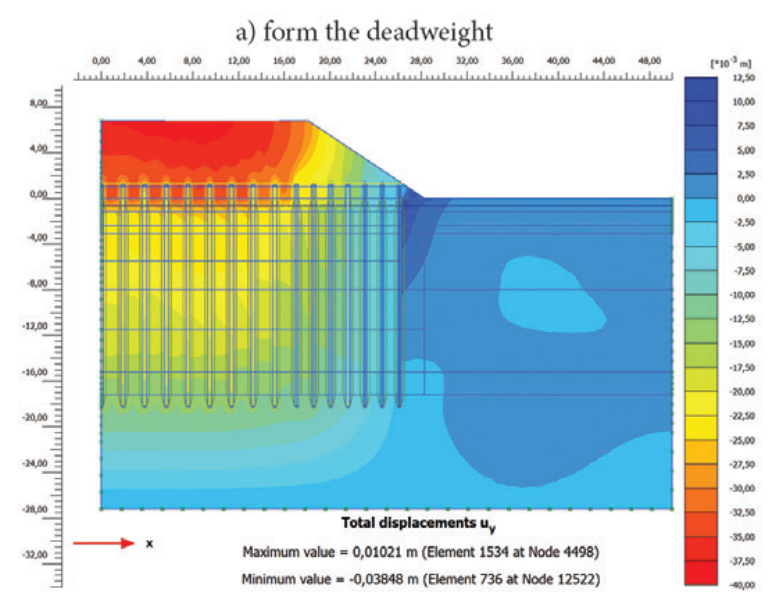

b) settlement from live load $25 \mathrm{kPa}$

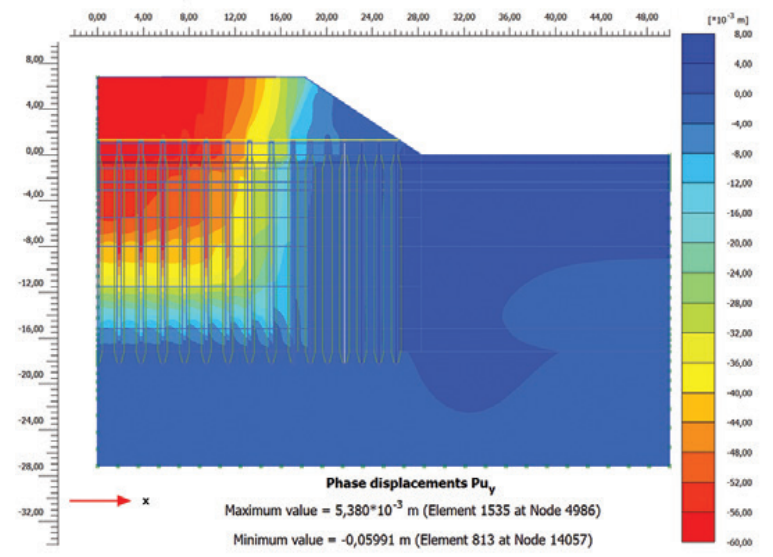

Fig. 9. Simulations of embankment settlement

inside. At both ends of each tube, steel H-beams of $1 \mathrm{~m}$ length were attached (Fig. 8a). The steel beams allowed to stabilize the tubes and were used for installation of the reference pins required to make geodetic measurements.

The settlement at the LPT level was measured using a high-precision differential pressure transducer (Fig. 8c). The device consists of a probe, inserted into the tube and pulling the tube using a rope. Inside the probe, there is a sensor with a membrane recording small pressure changes to determine relative height of the probe. The relative height readings were converted to absolute level data based on geodetic measurements taken at the reference pins located on both sides of each tube.

The initial tests confirmed that the accuracy of settlement measurements with the applied system was less than $1 \mathrm{~mm}$. It is noted that this device shows a measurement precision on other geodetic systems, e.g., terrestrial laser scanners (Bernat et al. (2014); Janowski et al. (2015); Laskowski, Szulwic (2014); Szulwic et al. (2016)). The hydrostatic levelling device, designed and produced by this monitoring system, was intended to control possible vertical displacements of the entire cross-section of the embankment. The measurements could be conducted within the transmission layer providing reliable information about its response.

\section{Results}

Numerical analysis was conducted with the use of Finite Element Method. The FEM model of the cross-section with organic soil thickness of $13 \mathrm{~m}$ (according to CPT 20) (Fig. 1b) was created. The soil was modelled by elasto-plastic material (CM); the linearly elastic material was adopted for reinforced columns. The equivalent live load equal $25 \mathrm{kPa}$ was assumed for the problem. Selected simulation results are shown in Fig. 9. The maximum total settlement achieved $9.9 \mathrm{~cm}$, its part; equal to $3.9 \mathrm{~cm}$ came from deadweight, the rest $6.0 \mathrm{~cm}$ was produced by the live load.

Structural displacements obtained by the observational method are shown in Fig. 10. The measurements corresponding to the above numerical results are plotted by the red line, corresponding to the day of launching the road S-61 to public transport (December 19, 2013). At that time, the maximum displacement reached $12 \mathrm{~cm}$, more than the displacement obtained by numerical analysis. The measured displacement profile (Fig. 10) is unsymmetrical along the road cross-section indicating that the soil parameters are irregular. The settlement process finally stabilized around one year after completion of the embankment construction. The maximum value of settlement during the observation period is about $150 \mathrm{~mm}$. 


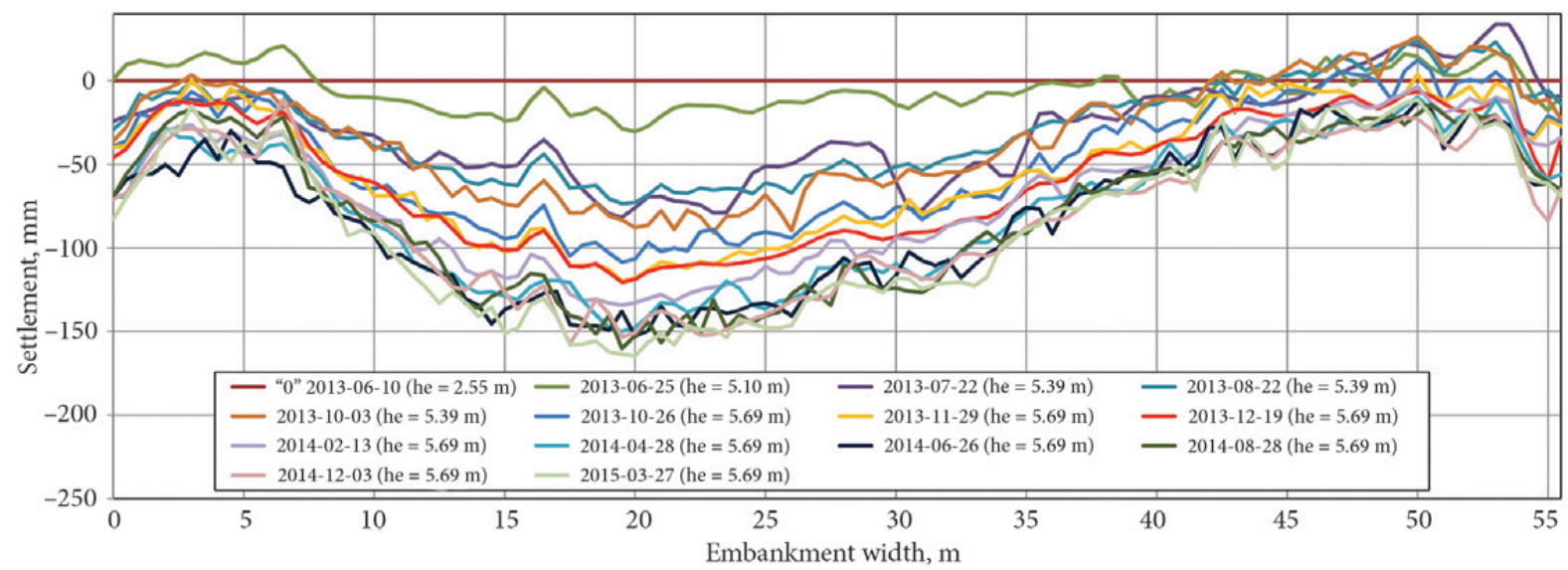

Fig. 10. Embankment settlement during construction (he - height of embankment)

Figure 11 presents the measurement results of compressive stress on column and subsoil. Within about 2 years of observation, the average pressure values per one column reached 4.2 $\mathrm{MPa}$, the average pressure values on subsoil were $26 \mathrm{kPa}$. The column pressure detected numerically was 4.8 MPa. The numerical results approximate the experimental ones well. It can be stated that the real behaviour of the embankment met the designer expectations (Sondermann, Topolnicki 2014). However, the interpretation of other measurement data is relatively complex. It requires extensive numerical simulations updated on data gained form the monitoring system. In the design procedures and embankment condition evaluation during operation only primary numerical parametric study was conducted, a further study aiming at the solution for the inverse problem is planned too.

\section{Conclusions}

The Load Transfer Platform with steel grid reinforcement is a kind of an innovative structure. For this reason, the scientists from Gdansk University of Technology and engineers from Keller Polska conducted joined research on road embankment with the use of numerical analysis and in situ observational method. The research team developed and implemented two prototype measurement systems: hydrostatic levelling of the embankment cross-section and long base multiple point extensometers mounted on the steel grid. Both systems provided reasonable results to carry out long-term structural observations. A lower sort of experience emerged in strain measurements on Controlled Stiffness Columns and steel grid with the use of short base vibrating wire strain gages. The test column was impacted by the installation of the adjacent columns. This process resulted in a high, temporary stress increase which consequently disturbed the interpretation of further measurements. A similar problem occurred in strain measurements in the steel grid. Some of the vibrating wire sensors were destroyed during backfilling and compaction of the transmission layer. Sensor damage happened despite the use of a thicker transmission layer and switching off roller vibrations.

Nevertheless, the collected results made a great insight into the embankment condition. The comparison
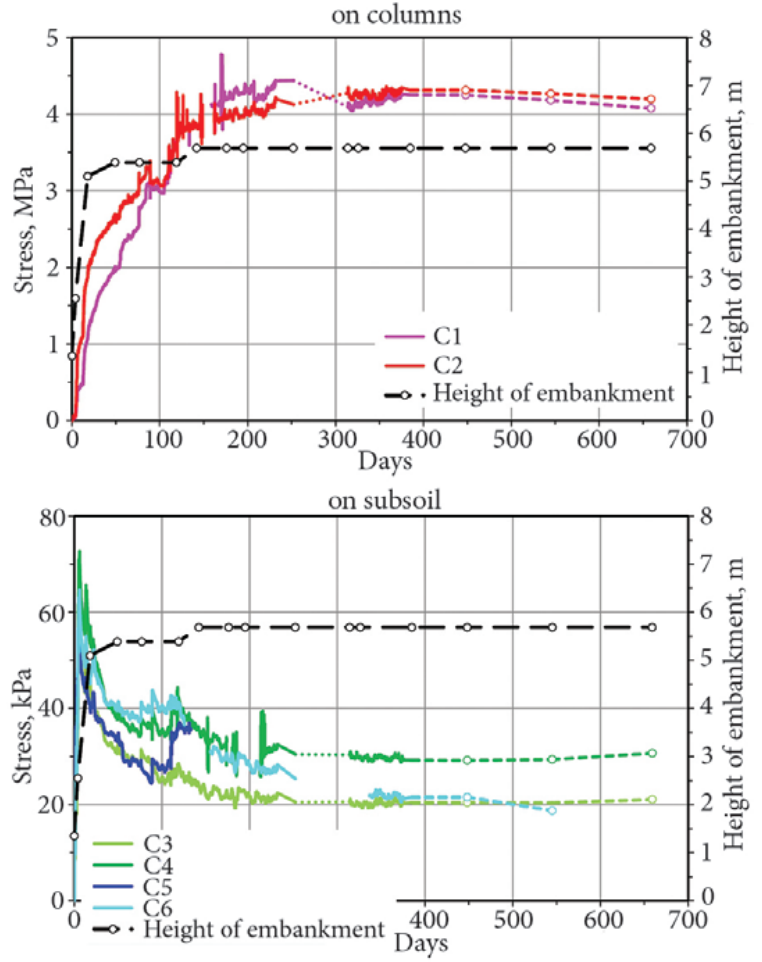

Fig. 11. Measured stresses

of the numerical and experimental results provided necessary evidence for the embankment numerical model validation. The results also allowed to finally stating that the innovative embankment reinforcement is working according to the design expectations. The proposed solution, i.e., Load Transfer Platform with steel grid reinforcement, reduce bending of the outer columns, taking assumed load level. The combination of numerical simulations and in situ measurements led to better understanding of structural behaviour, to mitigate risk and possibly optimize innovative engineering solutions.

\section{References}

Bernat, M.; Janowski, A.; Rzepa, S.; Sobieraj-Żłobińska, A.; Szulwic, J. 2014. Studies on the Use of Terrestrial Laser Scanning in the Maintenance of Buildings Belonging to the Cultural 
Heritage, in $14^{\text {th }}$ Geoconference on Informatics, Geoinformatics and Remote Sensing, SGEM, vol. 3. 17-26 June 2014, Albena, Bulgaria, 307-318.

https://doi.org/10.5593/SGEM2014/B23/S10.039

Boerez, J.; Hinderer, J.; Rivera, L.; Jones, M. 2012. Analysis and Modeling of the Effect of Tides on the Hydrostatic Leveling System at CERN, Survey Review, Maney Publishing 44(327): 256-264. https://doi.org/10.1179/1752270611Y.0000000031

Janowski, A.; Szulwic, J.; Tysiac, P.; Wojtowicz, A. 2015. Airborne and Mobile Laser Scanning in Measurements of Sea Cliffs on the Southern Baltic, in $15^{\text {th }}$ International Multidisciplinary Scientific GeoConference SGEM, Book 1, vol. 2. 18-24 June 2015, Albena, Bulgaria, 17-24. https://doi.org/10.5593/SGEM2015/B12/S2.003

Kaminski, W.; Makowska, K.; Miśkiewicz, M.; Szulwic, J.; Wilde, K. 2015. System of Monitoring of the Forest Opera in Sopot Structure and Roofing, in $15^{\text {th }}$ International Multidisciplinary Scientific GeoConference SGEM Book 2, vol. 2., 18-24 June 2015, Albena, Bulgaria, 471-482. https://doi.org/10.5593/SGEM2015/B22/S9.059

Laskowski, P.; Szulwic, J. 2014. Royal Chapel in Gdansk. Study of Facility Inventory with the Usage of Laser Scanning within the Frames of Student Project, in $7^{\text {th }}$ International Conference on Education, Research and Innovation, ICERI2014. 17-19 November 2014, Sevilie, Spain, 1698-1707. https://doi.org/10.13140/2.1.4260.8322

Mariak, A.; Miśkiewicz, M.; Meronk, B.; Pyrzowski, Ł.; Wilde, K. 2016a. Reference FEM Model for SHM System of Cable-Stayed Bridge in Rzeszów. Advances in Mechanics: Theoretical, Computational and Interdisciplinary Issues, Taylor \& Francis Group: 383-387.

Mariak, A.; Chróścielewski, J.; Sabik, A.; Meronk, B.; Wilde, K. 2016b. Monitoring of Concrete Curing in Extradosed Bridge Supported by Numerical Simulation, Advances in Science and Technology Research Journal 10(32): 254-262. https://doi.org/10.12913/22998624/66186

Miśkiewicz, M.; Mitrosz, O.; Brzozowski, T. 2017a. Preliminary Field Tests and Long-Term Monitoring as a Method of Design Risk Mitigation: a Case Study of Gdańsk Deepwater Container Terminal, Polish Maritime Research 24(3): 106-114. https://doi.org/10.1515/pomr-2017-0095

Miśkiewicz, M.; Pyrzowski, Ł.; Chróścielewski, J.; Wilde, K. 2016. Structural Health Monitoring of Composite Shell Footbridge for Its Design Validation, in 2016 Baltic Geodetic Congress (BGC Geomatics). 2-4 June 2016, Gdansk, Poland, 228-233. https://doi.org/10.1109/BGC.Geomatics.2016.10

Miśkiewicz, M.; Pyrzowski, Ł.; Wilde, K.; Mitrosz, O. 2017b. Technical Monitoring System for a New Part of Gdańsk Deepwater Container Terminal, Polish Maritime Research 24(s1): 149-155. https://doi.org/10.1515/pomr-2017-0033

Patel, D.; Nicholson, D.; Huybrechts, N.; Maertens, J. 2007. The Observational Method in Geotechnics, in Proc. of XIV European Conference on Soil Mechanics and Geotechnical Engineering, vol. 1. Ed. by Cuéllar, V.; Dapena, E.; Alonso, E.; Echave, J. M.; Gens, A.; de Justo, J. L.; Oteo, C.; Rodríguez-Ortiz, J. M.; Sagaseta, C.; Sola, P.; Soriano, P., 24-27 September 2007, Madrid, Spain. Rotterdam, The Netherlands: Millpress Science Publishers, 371-380.

Rucka, M.; Wilde, K. 2013. Experimental Study on Ultrasonic Monitoring of Splitting Failure in Reinforced Concrete, Journal of Nondestructive Evaluation 32(4): 372-383. https://doi.org/10.1007/s10921-013-0191-y

Simon, B. 2013. Recommendations for the Design, Construction and Control of Rigid Inclusion Ground Improvement. Paris, Presses des Ponts. ISBN 978-2-85978-470-6

Sondermann, W.; Topolnicki, M. 2014. Bemessung von Lastverteilungsschichten mit unterschiedlichen Berechnungsmodellen und Vergleich mit in-Situ Messungen, in $10^{\text {th }}$ International Conference on Geosynthetics (10ICG). Ed. by Heerten, G., 23-26 September 2014, Berlin, Germany (in German)

Szulwic, J.; Tysiac, P.; Wojtowicz, A. 2016. Coastal Cliffs Monitoring and Prediction of Displacements Using Terrestial Laser Scanning, in Proc. of 2016 Baltic Geodetic Congress (Geomatics). Ed. by Žak, M.; Žurowski, A., 2-4 June 2016, Gdansk, Poland. IEEE Service Center, 61-66.

https://doi.org/10.1109/BGC.Geomatics.2016.20

Topolnicki, M. 2013. Ryzyko związane ze wzmacnianiem gruntu za pomocą kolumn o różnej sztywności, in Proc. of XXVIII Ogólnopolskie Warsztaty Pracy Projektanta Konstrukcji. 5-8 March 2013, Wisła, Poland (in Polish)

Wilde, K.; Miśkiewicz, M.; Chróścielewski, J. 2013. SHM System of the Roof Structure of Sports Arena, in "Olivia", Proc. of the $9^{\text {th }}$ International Workshop on Structural Health Monitoring (IWSHM 2013). Ed. by Chang, F. K., 10-12 September 2013, Dohrmann Grove, Stanford University, CA, USA. 10-12.

Received 15 February 2017; accepted 19 August 2017 